\title{
NILAI PENDIDIKAN DALAM BUDAYA MENANAM PADI SUKU DAYAK KANAYATN DI KALMANTAN BARAT
}

\author{
The Value of Education in Paddy Cultivation of Kanayatn Dayak in West \\ Kalimantan
}

Oleh Neni Puji Nur Rahmawati

Balai Pelestarian Sejarah dan Nilai Tradisional Pontianak

Jl. Letjend. Sutoyo Pontianak 78121

E-mail:neni_bpsntptk@yahoo.co.id

\begin{abstract}
Abstrak
Sebagian besar Suku Dayak Kanayatn menghuni wilayah Provinsi Kalimantan Barat, khususnya di daerah Kabupaten Pontianak, Kabupaten Landak, dan Kabupaten Bengkayang. Selain itu, ada juga yang tinggal di Kabupaten Sanggau, Kabupaten Sambas, dan Kabupaten Ketapang. Masyarakat Dayak Kanayatn memiliki kearifan lokal dalam mengelola alam dan lingkungannya, misalnya dalam perladangan. Padi adalah tanaman yang sakral bagi masyarakat Dayak Kanayatn. Kehadiran padi dalam masyarakat Dayak Kanayatn diidentikkan dengan kehidupan. Mereka sangat menghormati padi, yang diwujudkan melalui aturan-aturan adat istiadat yang harus dilaksanakan, mulai dari pembukaan lahan sampai memanen. Kearifan lokal tersebut mengandung nilai-nilai luhur yang bersifat mendidik dan perlu untuk dicontoh. Tujuan penelitian ini adalah untuk mengetahui salah satu kebudayaan pada suku Dayak Kanayatn, terutama dalam budaya menanam padi yang mempunyai cara yang khas. Selain itu ingin menggali nilai-nilai pendidikan di balik kearifan lokal dalam proses menanam padi. Pendidikan dan kebudayaan sangat erat sekali hubungannya, keduanya saling mendukung satu sama lainnya. Setelah dicermati, ternyata dalam budaya menanam padi pada masyarakat Dayak Kanayatn mengandung beberapa nilai pendidikan, di antaranya: mendidik kita agar pandai bersyukur kepada Tuhan, mendidik kita untuk saling membantu dengan sesama, rajin berdoa kepada Tuhan, bisa berbagi dengan sesama, selalu melestarikan sastra lisan dan bahasa asli, dan agar bisa hidup sabar.
\end{abstract}

Kata kunci: Dayak Kanayatn, kearifan lokal.

\section{Abstract}

The Dayak Kanayatn is a dry rice-field farmer inhabiting the province of West Kalimantan, mainly in Kabupaten Pontianak, Kabupaten Landak and Kabupaten Bengkayang. A small number of them live in Kabupaten Sanggau, Kabupaten Sambas and Kabupaten Ketapang. They cultivate paddy (Oryza sativa), and paddy is a sacred plant for them. Paddy means life, so they have sophisticated traditional ceremony in giving honour to the plant, starting from clearing land to harvesting. This local wisdom has highly 
educational values for us to follow. The purpose of this study is to gain further knowledge about local wisdom of the Dayak Kanayatn, especially in the educational value in the ceremony of cultivating paddy. It is undoubtedly known that education is a part of culture and they both are closely related.The result shows that that are many educational values in the process, e.g. the value of the importance of helping each other and how to be grateful to God for everything He has given them. The ceremony also teaches us to preserve oral tradition, including literatures and native languages.

Keywords: Dayak Kanayatn, local wisdom.

\section{A. PENDAHULUAN}

Masyarakat Dayak di Pulau Kalimantan ${ }^{1}$ terutama suku Dayak Kanayatn di Kalimantan Barat, mempunyai cara tersendiri (kearifan lokal) dalam mengelola alam dan lingkungannya. Mereka menggunakan perspektif budaya dalam mengelola alam dan lingkungannya. Hal ini sangat berbeda dengan masyarakat lain pada umumnya yang cenderung menggunakan perspektif bisnis.

Pengelolaan alam yang paling sederhana adalah kegiatan menanam padi. Banyak aturan adat istiadat yang dilakukan dalam proses menanam padi mulai dari pembukaan lahan sampai memanen. Tanaman padi adalah tanaman yang sakral bagi masyarakat Dayak Kanayatn ${ }^{2}$.

${ }^{1}$ Pulau Kalimantan merupakan pulau terbesar ketiga setelah Greenland dan Papua. Luasnya $746.305 \mathrm{~km}^{2}$, sedangkan Greenland 2.175.600 $\mathrm{km}^{2}$, dan Papua $808.510 \mathrm{~km}^{2}$. Secara geopoloitis, Pulau Kalimantan merupakan satu-satunya pulau di dunia yang dimiliki oleh tiga negara sekaligus, yaitu Indonesia, Malaysia dan Brunei Darussalam. Namun demikian, sebagian besar pulau ini masuk ke dalam wilayah Indonesia, yaitu seluas $549.032 \mathrm{~km}^{2}$ atau $73 \%$ dari luas daratannya. Pulau Kalimantan yang merupakan wilayah Negara Indonesia meliputi: Kalimantan Barat, Kalimantan Timur, Kalimantan Tengah dan Kalimantan Selatan.

${ }^{2}$ Kanayatn atau nganayatn artinya "membawa persembahan kepada Jubata karena semua pekerjaan telah selesai. Dalam ritual tersebut terdapat sesajen untuk dipersembahkan kepada Jubata (Tuhan) dalam upacara adat dengan nyangahatn.
Setelah dicermati secara mendalam, ternyata dalam budaya menanam padi pada masyarakat Dayak Kanayatn di Kalimantan Barat mengandung nilai-nilai luhur yang bersifat mendidik dan perlu untuk dicontoh. Apalagi di era modernisasi sekarang ini, pendidikan karakter menjadi bahasan yang utama. Banyak hal yang bersifat tradisional sudah banyak ditinggalkan karena adanya pengaruh kemajuan teknologi. Banyak hal yang lebih condong untuk berkiblat ke arah kemajuan teknologi. Hal ini memungkinkan semakin lunturnya hal-hal yang bersifat tradisional. Hal inilah yang melatarbelakangi mengapa penelitian ini perlu dilakukan.

Tujuan penelitian ini adalah ingin mengetahui mengenai kebudayaan suku Dayak Kanayatn, salah satunya dalam budaya menanam padi yang mempunyai cara-cara tersendiri/khas ${ }^{3}$. Tujuan lainnya yaitu ingin menggali nilai-nilai di balik kearifan lokal masyarakat Dayak Kanayatn dalam proses menanam padi (dari proses menanam hingga memetik hasilnya). Nilainilai yang akan dikaji khususnya yang berkaitan dengan pendidikan. Selain itu, penelitian ini juga ingin mengetahui upacara-upacara adat yang menyertai dalam proses menanam padi tersebut.

Ruang lingkup materi adalah segala hal yang berkaitan dengan kearifan lokal masyarakat Dayak Kanayatn dalam proses menanam padi, baik prosesnya maupun

\footnotetext{
3 Bisa juga disebut dengan kearifan lokal, di mana kearifan lokal merupakan gagasangagasan atau nilai-nilai, pandangan-pandangan setempat (lokal) yang bersifat bijaksana, penuh kearifan, bernilai baik, yang tertanam dan diikuti oleh seluruh anggota masyarakatnya.
} 
upacara-upacara adat yang menyertai dalam proses menanam padi tersebut. Sedangkan ruang lingkup wilayahnya meliputi Kabupaten Pontianak, dengan mayoritas masyarakat Dayak Kanayatn tinggal di wilayah ini.

Metode yang digunakan dalam penelitian ini adalah penelitian kualitatif yang bersifat deskriptif. Metode dalam pengumpulan data yaitu melalui penelitian pustaka dan pengamatan/penelitian di lapangan. Penelitian pustaka dilakukan dengan mencari buku-buku, majalahmajalah dan segala bentuk sumber tertulis yang ada hubungannya dengan permasalahan yang akan dibahas, sebagai bekal untuk penelitian di lapangan. Selain itu dengan mencari buku-buku yang memuat tentang berbagai teori yang ada relevansinya dengan permasalahan pada penelitian ini yang akhirnya dapat membantu dalam penggarapan analisis. Sedangkan penelitian di lapangan dilakukan dengan metode wawancara, yaitu dengan melakukan wawancara secara mendalam (depth interview) kepada nara sumber kunci (key informan) yang menguasai tentang materi-materi yang diperlukan dalam penelitian ini.

Berbicara mengenai pendidikan dan kebudayaan memang tak bisa dipisahkan. Ketika manusia membentuk pendidikan secara utuh, tentu saja melalui proses kebudayaan-kebudayaan tertentu. Hal itu menunjukkan bahwa kebudayaan sangat memengaruhi pendidikan bagi kehidupan umat manusia. Mengenai teori/konsep yang berhubungan dengan topik penelitian ini dapat dikemukakan beberapa konsep sebagai berikut.

Pendidikan secara praktis tak dapat dipisahkan dengan nilai-nilai budaya. Dalam menjaga dan melestarikan kebudayaan sendiri, pendidikan memiliki peranan yang penting. Keduanya sangat erat sekali hubungannya karena saling melengkapi dan mendukung antara satu sama lainnya. Tujuan pendidikan adalah melestarikan dan selalu meningkatkan kebudayaan itu sendiri. Dengan adanya pendidikan, kebudayaan diwariskan dari generasi ke generasi selanjutnya. Masyarakat mencita-citakan terwujudnya masyarakat dan kebudayaan yang lebih baik ke depannya, yang diiringi dengan semakin majunya tingkat pendidikan.

Kebudayaan sebagai hasil budi manusia, dalam hal berbagai bentuk dan manifestasinya, dikenal sepanjang sejarah sebagai milik manusia yang selalu berkembang dan berubah serta membina manusia untuk menyesuaikan diri dengan perubahan-perubahan kultural dan tantangan zaman tradisional untuk memasuki zaman modern.

Manusia sebagai makhluk berakal dan berbudaya selalu berupaya untuk mengadakan perubahan-perubahan. Dengan sifatnya yang kreatif dan dinamis, manusia terus berevolusi meningkatkan kualitas hidup yang semakin terus maju. Makin lama daya rasa, cipta dan karsa manusia telah dapat mengubah alam menjadi sesuatu yang berguna. Kebudayaan merupakan karya manusia yang mencakup di antaranya filsafat, kesenian, kesusastraan, religi, penafsiran dan penilaian mengenai lingkungan ${ }^{4}$. Pendidikan dalam pengertian yang sederhana dan umum adalah sebagai usaha manusia untuk menumbuhkan dan mengembangkan potensi-potensi pembawaan baik jasmani maupun rohani sesuai dengan nilai-nilai yang ada dalam masyarakat.

Adapun menurut Carter V.Good dalam Dictionary of Education, pendidikan mengandung pengertian:

1. Proses perkembangan kecakapan seseorang dalam bentuk sikap dan prilaku yang berlaku dalam masyarakatnya.

2. Proses sosial dimana seseorang dipengaruhi oleh sesuatu lingkungan yang terpimpin (misalnya sekolah) sehingga dapat mencapai kecakapan sosial dan mengembangkan pribadinya.

Sedangkan menurut konsep yang dikemukakan oleh Freeman Butt dalam bukunya yang terkenal Cultural History of

\footnotetext{
${ }^{4}$ Diunduh dari http://hadirukiyah.blogspot.com/2010/07/hubung an-kebudayaan-dengan-pendidikan.html, pada hari: Senin, 27 September 2011
} 
Western Education bahwa: pendidikan adalah kegiatan menerima dan memberikan pengetahuan sehingga kebudayaan dapat diteruskan dari generasi ke generasi berikutnya.

Menurut Hasan Langgulung dalam Asas-Asas Pendidikan Islam menyatakan bahwa pendidikan adalah aktifitas yang dikerjakan oleh pendidikan dan filsafatfilsafat untuk menjelaskan proses pendidikan, menyelaraskan, mengkritik dan merubahnya berdasarkan masalah-masalah kontradiksi budaya.

Dengan demikian, sudah jelas bahwa pendidikan dan kebudayaan sangat erat sekali hubungannya karena keduanya berkesinambungan dan saling mendukung satu sama lainnya. Dalam konteks ini dapat dilihat hubungan antara pendidikan dengan tradisi budaya serta kepribadian suatu masyarakat betapapun sederhananya masyarakat tersebut. Hal ini dapat dilihat bahwa tradisi sebagai muatan budaya senantiasa terlestarikan dalam setiap masyarakat, dari generasi ke generasi. Hubungan ini tentunya hanya akan mungkin terjadi bila para pendukung nilai tersebut dapat menuliskannya kepada generasi mudanya sebagai generasi penerus.

\section{B. HASIL DAN BAHASAN}

1. Mengenal Suku Dayak Kanayatn Di Kalimantan Barat

Dayak Kanayatn adalah salah satu dari sekian ratus subsuku Dayak yang mendiami Pulau Kalimantan ${ }^{5}$. Suku Dayak

5 Menurut Tjilik Riwut dalam bukunya yang berjudul Maneser Panatau Tatu Hiang, Menyelami Kekayaan Leluhur, Hal.64, mengatakan bahwa di seluruh Pulau Kalimantan terdiri dari 405 suku kecil-kecil dan setiap daerah memiliki bahasa daerah sendiri. Dari seluruh suku bangsa Dayak yang ada di Pulau Kalimantan dapat digolongkan ke dalam tujuh gugusan suku-suku bangsa induk. Ketujuh suku bangsa induk tersebut adalah suku bangsa Dayak Ngaju, Suku bangsa Dayak Apu Kayan, Suku bangsa Dayak Iban, Suku bangsa Dayak Klemantan, Suku Dayak Murut, Suku Dayak Punan dan Suku Dayak Ot-Danum. Sedangkan di Kalimantan Barat sendiri menurut penelitian yang telah dilakukan oleh Institut Dayakologi, di
Kanayatn tepatnya berada di daerah Kabupaten Pontianak, Kabupaten Landak, serta Kabupaten Bengkayang, sebagian kecil di Kabupaten Ketapang serta Kabupaten Sanggau. Apabila dilihat dari segi penduduknya, Suku Dayak Kanayatn ini dapat dikatakan relatif maju bila dibandingkan dengan Suku Dayak yang lain, seperti Dayak Taman, Dayak Iban, Dayak Bakati', Dayak Ribun, Dayak Dosan dan sebagainya. Masyarakat Suku Dayak Kanayatn ini bermukim di wilayah Kabupaten Pontianak di mana wilayah ini adalah yang paling dekat dengan ibu kota Provinsi Kalimantan Barat.

Bila dilihat dari sudut pandang geografis, penyebaran masyarakat Dayak Kanayatn sangat luas. Selain menyebar di sebagian besar Kabupaten Pontianak, juga menyebar di berbagai wilayah di antaranya di Kabupaten Landak, Kabupaten Bengkayang, Kabupaten Sanggau, Kabupaten Sambas dan sedikit di Kabupaten Ketapang. Namun demikian, bila dilihat dari jumlah populasinya, suku Dayak Kanayatn ini tidak sebanyak Suku Dayak yang lain seperti Dayak Iban. Di Kabupaten Pontianak, Suku Dayak Kanayatn merupakan sub Dayak yang terbesar.

Dilihat dari segi agama dan kepercayaan, Dayak Kanayatn masih banyak yang menganut aliran kepercayaan atau animisme di samping menganut agama resmi yang ada. Aliran kepercayaan ini bagi mereka merupakan "agama asli". Masyarakat Dayak Kanayatn sendiri menyebutnya dengan istilah "premahan". Bagi penganutnya, agama ini sangat dipahami dan ditaati. Dalam hal melaksanakan ibadahnya, mereka menyebut Nyangahatn Ka Jubata (sembahyang atau berdoa kepada Tuhan pencipta alam semesta).

Meskipun secara resmi mereka telah menganut agama formal (agama yang diakui oleh pemerintah), tetapi dari masyarakat itu lebih banyak yang mengaku menganut aliran kepercayaan "premahan" tersebut, akan tetapi dalam pengamalannya ternyata

Kalimantan Barat ada terdapat subsuku dengan 168 bahasa Dayak. 
pengaruh adat Dayak masih sangat dominan. Dalam kehidupan sehari-hari segala aktifitasnya masih dipengaruhi oleh kepercayaan lama. Mereka masih sangat percaya dan berpendapat bahwa setiap warga Dayak ini tidak boleh sekali-kali melupakan adatistiadat nenek moyang, apalagi sampai mencemoohkan ataupun membuang adat.

Pantangan atau tabu sebisanya harus ditaati agar mereka selamat dari bahaya. Mereka percaya bahwa di sekeliling tempat mereka tinggal terdapat berbagai jenis makhluk yang memiliki sifat baik dan sifat buruk. Mereka selalu berusaha menjaga jangan sampai makhluk-makhluk tersebut marah dengan selalu berbuat baik dan mematuhi segala aturan adat yang berlaku.

Pakaian tradisional Dayak Kanayatn terbuat dari kulit tarab atau kapuak/ kapoa'. Bajunya berbentuk rompi yang disebut baju marote atau baju uncit. Cawatnya terbuat dari kain tenun atau kulit kayu yang disebut kapoa. Serta mahkota atau ikat kepala yang dalam bahasa ahe disebut tangkulas. Tangkulas ini biasanya dihiasi dengan bulu ruai/kuau raja, serta bulu enggang. Terkadang, jika bulu burung Ruai tidak ada, bisa diganti dengan anjuang merah. Upacara adat yang biasa diadakan oleh suku ini antara lain Naik Dango, Muakng Rate, Gawai Dayak, dan lain-lain.

Religi asli suku Dayak Kanayatn tidak terlepas dari adat istiadat mereka. Bahkan dapat dikatakan adat menegaskan identitas religius mereka. Dalam praktik sehari-hari, orang Dayak Kanayatn tidak pernah menyebut agama sebagai normativitas mereka, melainkan adat. Sistem religi ini bukanlah sistem Hindu Kaharingan seperti yang dikenal oleh orang-orang pada umumnya.

Orang Kanayatn menyebut Tuhan dengan istilah Jubata. Jubata inilah yang dikatakan menurunkan adat kepada nenek moyang Dayak Kanayatn yang berlokasi di Bukit Bawakng (sekarang masuk wilayah Kabupaten Bengkayang). Dalam mengungkapkan kepercayaan kepada Jubata, mereka memiliki tempat ibadah yang disebut Panyugu atau Padagi. Selain itu diperlukan juga seorang imam panyangahatn yang menjadi seorang penghubung antara manusia dengan Jubata (Tuhan).

Sekarang ini banyak orang Dayak Kanayatn yang menganut agama Kristen dan segelintir memeluk Islam. Kendati sudah memeluk agama, tidak bisa dikatakan bahwa orang Dayak Kanayatn meninggalkan adatnya. Hal menarik ialah jika seorang Dayak Kanayatn memeluk agama Islam, ia tidak lagi disebut Dayak, melainkan Melayu atau orang laut.

Bahasa dalam masyarakat Dayak Kanayatn memakai bahasa ahe/nana' serta damea/jare dan yang serumpun. Sebenarnya secara isologis (garis yang menghubungkan persamaan dan perbedaan kosa kata yang serumpun) sangat sulit merinci khazanah bahasanya. Ini disebabkan bahasa yang dipakai sarat dengan berbagai dialek dan juga logat pengucapan. Beberapa contohnya ialah: orang Dayak Kanayatn yang mendiami wilayah Meranti (Landak) yang memakai bahasa ahe/nana terbagi lagi ke dalam bahasa behe, padakng bekambai, dan bahasa moro. Dayak Kanayatn di kawasan Menyuke (Landak) terbagi dalam bahasa satolo-ngelampa, songga batukng-ngalampa dan angkabakng-ngabukit. Selain itu, percampuran dialek dan logat menyebabkan percampuran bahasa menjadi bahasa baru.

Banyak generasi Dayak Kanayatn saat ini tidak mengerti bahasa yang dipakai oleh para generasi tua. Dalam komunikasi saat ini, banyak kosa kata bahasa Indonesia yang diadopsi dan kemudian "di-Dayakkan". Misalnya: bahasa Ahe asli: lea, bahasa Indonesia: seperti, bahasa Ahe sekarang: saparati. Bahasa yang dipakai oleh generasi muda sekarang mudah dimengerti karena mirip dengan bahasa Indonesia atau Melayu.

Suku Dayak merupakan bagian dari masyarakat adat. Masyarakat adat adalah komunitas-komunitas yang hidup berdasarkan asal usul keturunan di atas suatu wilayah adat, yang memiliki kedaulatan atas tanah dan kekayaan alam, kehidupan sosialbudayanya diatur oleh hukum adat dan lembaga adat yang mengelola keberlangsungan hidup masyarakatnya.

Hukum adat Dayak Kanayatn mempunyai satuan wilayah teritorial yang disebut 
binua. Binua merupakan wilayah yang terdiri dari beberapa kampung (dulunya radakng/bantang). Masing masing binua mempunyai otonominya sendiri, sehingga komunitas binua yang satu tidak dapat mengintervensi hukum adat di binua lain. Setiap binua dipimpin oleh seorang timanggong (kepala desa). Timanggong memiliki jajaran-bawahan yaitu pasirah (kepala dusun) dan pangaraga (ketua RW/RT). Ketiga pilar inilah yang menjadi lembaga adat Dayak Kanayatn.

Sistem pertalian darah suku Dayak Kanayatn menggunakan sistem bilineal/ parental (ayah dan ibu). Dalam mengurai hubungan kekerabatan, seorang anak dapat mengikuti jalur ayah maupun ibu. Hubungan kekerabatan terputus pada sepupu delapan kali. Hubungan kekerabatan ini penting karena hubungan ini menjadi tinjauan terutama pada perkara perkawinan. Mungkin hal ini dimaksudkan agar tidak merusak keturunan.

\section{Asal-usul Padi Menurut Masyarakat Dayak Kanaytn}

Masyarakat Dayak Kanayatn masih hidup dalam tradisi lisan ${ }^{6}$. Oleh karena itu, asal usul padi ini dapat ditelusuri melalui cerita rakyat yang merupakan bagian dari tradisi lisan. Di Kalimantan Barat, cerita tentang asal usul padi ada dua versi, yaitu versi Melayu (Sambas) dan versi Dayak (Kanayatn) (Hendraswati, 1999: 3).

Cerita rakyat tentang asal-usul padi di kalangan masyarakat Dayak Kanayatn masih sangat dikultuskan, masih sangat dihormati, dan bahkan cerita rakyat itu ada yang menganggap sebagai mite/mitos bagi masyarakat Dayak Kanayatn itu sendiri. Dalam hal ini, mitos dapat diartikan sebagai cerita rakyat yang dianggap benar-benar terjadi serta dianggap suci oleh pemiliknya.

\footnotetext{
6 Tradisi lisan terdiri dari: ungkapan-ungkapan tradisional (peribahasa, pepatah, seloka), pernyataan tradisional (teka-teki), cerita prosa rakyat ( mite, legenda, dongeng, fable, cerita jenaka), mantra-mantra dan juga nyanyian rakyat (Hendraswati, 1999: 3).
}

Cerita rakyat tentang asal-usul padi di kalangan masyarakat Dayak Kanayatn ini dikenal dengan judul Ne' Baruakng Kulup. $\mathrm{Ne}$ ' Baruakng merupakan anak dari $\mathrm{Ne}^{\prime}$ Jaek dan $\mathrm{Ne}^{\prime}$ Baruakng, ini merupakan tokoh utama dalam cerita tentang asal-usul padi. Dalam cerita rakyat $\mathrm{Ne}$ ' Baruakng Kulup ini, Ne' Baruakng berperan sebagai tokoh utama yang digambarkan sebagai tokoh penurun padi ke dunia (talino) setelah upaya ayahnya (Ne' Jaek) gagal akibat sikapnya yang tidak diterima oleh ketujuh saudaranya. Hal ini disebabkan pada awalnya Ne' Baruakng pergi untuk mencari kepala kayau (pergi mengayau ${ }^{7}$ guna memenuhi salah satu syarat perkawinannya, tetapi yang didapat bukanlah kepala kayau melainkan biji padi.

\section{Menanam Padi dalam Semangat Budaya Dayak Kanayatn}

Masyarakat Dayak Kanayatn mempunyai cara tersendiri dalam mengelola alam dan lingkungannya. Masyarakat Dayak terutama Suku Dayak Kanayatn di Kalimantan Barat bisa menggunakan perspektif budaya dalam mengelola alam dan lingkungannya. Hal ini sangat berbeda dengan masyarakat lain pada umumnya yang cenderung menggunakan perspektif bisnis. Pengelolaan alam yang paling sederhana adalah kegiatan menanam padi. Tanaman padi adalah tanaman yang sakral bagi masyarakat Dayak Kanayatn. ${ }^{8}$ Tidak heran banyak aturan adat istiadat yang harus dijalankan dalam proses menanam padi mulai dari pembukaan lahan sampai memanen.

\footnotetext{
${ }^{7}$ Mengayau adalah istilah orang Dayak yang artinya memenggal kepala.
}

8 Tentang asal usul padi ini tertuang dalam sebuah cerita rakyat yang berjudul $N e^{\prime}$ Baruakng Kulup, menceritakan bahwa padi diturunkan dari atas langit, ke bumi. Ne' Baruakng adalah anak $N e^{\prime} J a^{\prime} e k$, yang berjasa memperoleh tangkai padi untuk pertama kalinya dari seekor burung pipit, yang membawanya di antara dua buah batu badangkop (batu kembar) dan sekarang dapat ditemui di Bukit Talaga. 
Kehadiran padi dalam masyarakat Dayak Kanayatn diidentikkan dengan kehidupan. Masyarakat Dayak Kanayatn menjadi masyarakat pecinta pertanian (khususnya padi), sehingga pekerjaan lain seolah-olah baru akan berarti apabila mendampingi pertanian. Karena besarnya penghormatan dan penghayatan pada padi, maka dalam kehidupan masyarakat Dayak Kanayatn timbullah kebiasaan-kebiasaan untuk menghormati padi dengan nilai yang sangat dalam, antara lain:

- Oleh karena masyarakat Dayak Kanayatn sangat menghargai padi, akhirnya tampak dalam perilaku petani yang menganggap bahwa membiarkan padi atau nasi yang jatuh di tanah atau di lantai adalah pantang (pamali'), walaupun hanya sebiji.

- Masyarakat Dayak Kanayatn mempunyai kebiasaan pantang untuk menjual padi hasil sawah atau ladangnya. Hal ini menumbuhkan tradisi lain bahwa jika seseorang memerlukan sesuatu yang berhubungan dengan padi atau sebaliknya, yang bersangkutan hanya boleh pinjam-meminjam atau tukarmenukar.

- Padi hasil panen ditempatkan dalam dango ${ }^{9}$ padi, agar dapat tersimpan dengan tenang dan aman. Lebih jauh ketenangan ini dapat diwujudkan dengan alunan lagulagu yang dikenal dengan tindan (lagu untuk menidurkan padi) (Hendraswati, 1999: 31-32).

Adapun proses-proses menanam padi yang dilakukan oleh masyarakat Suku Dayak Kanayatn adalah sebagai berikut:

Menanam padi akan dimulai dari tahun baru padi yang biasanya jatuh pada

9 Dango, adalah bangunan kecil yang dipergunakan untuk menyimpan padi hasil panen pada masyarakat Dayak Kanayatn, dango sama artinya dengan lumbung padi. Bahkan kegiatan untuk memasukkan padi ke dalam dango ini, bagi masyarakat Dayak Kanayatn merupakan kegiatan yang sangat sakral. Oleh karena itu, dalam masyarakat Dayak Kanayatn dikenal dengan adanya upacara adat secara besar-besaran yaitu upacara adat Naik Dango yang dilaksanakan secara rutin setahun sekali. bulan Juni-Agustus, tergantung cuaca dan hasil panen sebelumnya. Tahun baru padi adalah waktu ladang baru dibuka. Sebelum pembukaan ladang biasanya diawali dengan masa pantang melakukan aktifitas selama tiga hari. Pembukaan ladang diawali dengan tebang lahan (nenteng pengawah). Kegiatan tebas tebang dilakukan secara kelompok, mirip sistem arisan di Jawa. Budaya gotong royong masih sangat kuat. Setelah tebas tebang dilakukan pembakaran. Hal ini dilakukan mengingat kondisi lahan yang bersifat asam (kadar $\mathrm{pH}$ yang rendah), pembakaran lahan akan meningkatkan kadar $\mathrm{pH}$ tanah sehingga tanah lebih subur. ${ }^{10}$ Untuk lahan basah/sawah maka kegiatan diawali dengan persiapan tebas rumput secara berkelompok. Beberapa masyarakat sudah menggunakan bahan kimia untuk membasmi rumput.

Menanam padi ladang akan dilakukan pada bulan Agustus-September yang hampir bersamaan dengan datangnya musim hujan. Kegiatan ini dilakukan secara kelompok dan biasanya kelompok tersebut sama dengan kelompok tebas tebang. Tanam padi juga dibarengi dengan tanam jagung dan padi sawah. ${ }^{11}$

Pada bulan Oktober-November, masyarakat melakukan kegiatan penyiangan rumput padi ladang dan sawah. Masyarakat biasa menginap di ladang. Masa ini disebut dengan istilah ngelamo (padi tumbuh). Dengan tumbuhnya padi di ladang atau sawah, maka masyarakat akan melakukan ucapan syukur dengan pantang melakukan aktivitas selama 3 hari.

\footnotetext{
${ }^{10}$ Namun, pembakaran ladang masyarakat Dayak sering dijadikan kambing hitam pencemaran udara atau kebakaran hutan, padahal fakta di lapangan masyarakat membakar ladang hanya sebatas keperluan untuk ladang padi mereka dan tidak mungkin menyebar ke area lain. Kebakaran hutan yang sering digembar-gemborkan sebagai pencemaran udara sering kali justru dilakukan oleh investor tertentu yang punya kepentingan atas lahan atau hutan.

${ }^{11}$ Dalam satu lahan yang ditanami lebih dari satu jenis tanaman dinamakan dengan tanaman tumpang sari.
} 
Bulan Desember-Februari adalah bulan menunggu panen. Biasanya masyarakat akan melakukan aktifitas lain di luar ladang. Di masa ini masyarakat akan membuat dangau atau rumah untuk menyimpan padi.

Panen pertama kali akan dilakukan pada bulan Maret-April. Kegiatan ngetam dengan ani-ani akan dilakukan oleh masyarakat. Masyarakat Dayak Kanayatn masih tabu memanen padi menggunakan alat lain, karena menurut kepercayaan masyarakat, alat selain ani-ani, akan menyakiti padi sehingga masyarakat bisa terkena tulah atau kejadian yang tidak menyenangkan. Di masa ini masyarakat akan melakukan matah padi (panen padi) yang akan didahului permohonan izin kepada alam sekaligus dilakukan pantang melakukan aktifitas ladang selama 3 hari.

Bulan April-Mei akan dilakukan kegiatan naik dangau atau kegiatan memasukkan padi ke dalam dangau, yaitu bangunan rumah sebagai tempat untuk menyimpan padi. Di Kabupaten Landak, acara naik dangau dilakukan secara meriah dan besar-besaran. Acara ini sering menjadi kunjungan wajib wisatawan dan media massa. Setelah naik dangau akan berlanjut masa pesta perkawinan dan sunatan. Di masa ini, kampung-kampung masyarakat Dayak Kanayatn dipenuhi oleh kegiatan keramaian hiburan rakyat. Selain hiburan tradisional, ada juga hiburan yang lain yang sudah melebur dengan masyarakat. Kegiatan pesta ini akan berlangsung hingga bulan Juni. Kegiatan pembukaan ladang akan dimulai lagi. Tahun baru padi kembali berlangsung.

\section{Nyangahatn: Upacara Adat Musim Tanam dan Panen Suku Dayak Kanayatn}

Asal usul upacara Nyangahatn ${ }^{12}$ adalah kepercayaan orang Dayak Kanayatn

12 Nyangahatn juga dapat disebut sebagai tata cara utama ekspresi religi suku Dayak. Nyangahatn menjadi bagian pokok dalam setiap bentuk upacara, dengan urutan tahapan yang terhadap Tuhan mereka yang bernama Jubata. Mereka meyakini bahwa Jubata telah memberikan rezeki yang melimpah pada pertanian mereka. Untuk itu, sebagai ungkapan rasa syukur dan terima kasih kepada Jubata, Suku Dayak Kanayatn melaksanakan upacara yang disebut Nyangahatn.

Upacara Nyangahatn juga diilhami ketaatan Suku Dayak Kanayatn terhadap adat yang telah diwariskan oleh leluhur mereka. Bagi orang Dayak Kanayatn, adat adalah aturan yang harus ditaati secara turun temurun. Upacara Nyangahatn pada umumnya dilakukan pada setiap siklus budidaya padi, baik pada saat mulai menanam atau seusai panen (patahunan). Melalui upacara ini, orang Dayak Kanayatn ingin menyampaikan rasa syukur kepada Jubata. Selain itu, mereka juga ingin mengadukan kepada Jubata tentang segala kesulitan mereka dalam mengelola pertanian, dan mereka memohon agar tanaman padi mereka baik, tidak diserang hama, dan mendapatkan panen yang melimpah. Upacara Nyangahatn biasanya akan ditutup dengan upacara lain yang lebih sederhana, yaitu upacara Naik Dango. Upacara ini biasanya dilakukan pada tanggal 27 April pada setiap tahunnya.

Upacara Nyangahatn biasanya dipimpin oleh petugas adat khusus yang menangani padi. Petugas ini disebut Tuha Tahutn atau Panyangahatn. Upacara dilakukan di sebuah tempat di dekat sawah (panyugu) atau bisa juga di rumah. Adapun waktunya adalah sesaat sebelum memulai tanam dan setelah panen.

Perlengkapan yang perlu disediakan dalam upacara ini antara lain: sesaji yang berupa nasi dua gare 'nasi dan garam', sirih masak (kapur, sirih, gambir, tembakau dan rokok daun nipah), tenkeatn (bibit padi yang sudah dipotong dan dipilih bulirnya yang bagus), inge (wadah pemungut padi), batu asahan, parang dan katam/anai-anai (alat pemotong padi).

baku, kecuali bahan, jumlah roh-roh, para Jubata yang diundang. 
Pelaksanaan upacara Nyangahatn secara umum dibagi menjadi dua tahap, yaitu persiapan dan pelaksanaan upacara. Adapun pada tahap pelaksanaan, upacara dibagi dalam dua proses besar, yaitu Nyangahatn Manta' (tanpa hewan qurban atau hewan qurban belum disembelih) dan Nyangahatn Masa' (hewan qurban sudah disembelih dan dimasak).

Dalam pelaksanaan upacara ini dibacakan tiga macam doa, salah satu di antaranya adalah doa mati' (doa hajat) yang dibaca oleh Panyangahatn (pemimpin upacara). Bunyi doa itu adalah:

"Asak, dua, talu, empat, lima, anam, tujuh.........Oh kita' Jubata yang badiapm kak aik dalam tanah tingi, puhutn ayak, puhutn tingi. Kita karamat ai' tanah nang mampu nunu ai' sakayu nyambong sengat. Kami bapinta kami bapadah, ame babadi kak kami talino manusia". (Artinya: satu, dua, tiga, empat, lima, enam, tujuh...Tuhan yang menguasai di air dalam, tanah tinggi, pohon kayu besar, pohon kayu tinggi. Penguasa air dan bumi yang mampu membakar air satu sungai, menyambung nyawa. Kami meminta dan mengabarkan, jangan memberikan wabah kepada manusia).

Adapun pantangan yang harus dijauhi selama menjalankan upacara adat ini, meliputi dua bagian, yaitu pada saat upacara berlangsung dan seusai upacara dilaksanakan. Pada saat upacara berlangsung, para warga yang ikut dalam upacara adat itu dilarang bersiul, karena hal itu akan mengganggu konsentrasi pemimpin upacara. Adapun seusai upacara, seluruh warga Dayak Kanayatn dilarang mencuri, merampok, membunuh, dan berbuat asusila. Hal itu akan membuat Jubata tidak akan mengabulkan segala doa yang dibacakan ketika upacara. Apabila pelanggaranpelanggaran itu dilakukan oleh warga Dayak Kanayatn, maka akan diberlakukan hukum adat yang berlaku dan telah disepakati bersama dalam masyarakat tersebut.

\section{Unsur-Unsur Pendidikan dalam Budaya Menanam Padi pada Masyarakat Dayak Kanayatn}

Kalau dicermati secara mendalam, dari proses menanam padi pada masyarakat Suku Dayak Kanayatn di Kalimantan Barat mulai dari proses pembukaan lahan, penanaman padi, hingga masa panennya, sebenarnya mengandung unsur-unsur/nilainilai positif yang bersifat mendidik. Dari budaya menanam padi ini bisa diambil beberapa manfaat, di antaranya:

1. Mata pencaharian mayoritas orang Dayak, khususnya Dayak Kanayatn adalah bertani. Dalam setiap masa tanam, keinginan mereka adalah mendapatkan panen yang melimpah. Orang Dayak Kanayatn memahami bahwa hal itu merupakan karunia yang diberikan oleh Jubata (Tuhan) mereka. Mereka mengungkapkan rasa terima kasih dengan menyelenggarakan upacara adat Nyangahatn. Pelaksanaan upacara adat ini sebenarnya mendidik kita agar pandai bersyukur atas semua karunia yang telah diberikan oleh Tuhan Yang Maha Esa. Selain itu, pelaksanaan upacara adat ini mengingatkan kita agar tidak melupakan atas rahmat yang telah diberikan oleh Tuhan karena melalui upacara adat tersebut disertai dengan pembacaan mantramantra yang pada intinya adalah wujud doa permohonan pada Yang Maha Kuasa.

2. Dalam proses menanam padi ini juga terdapat nilai kebersamaan. Pelaksanaan upacara adat Nyangahatn ini secara bersama-sama oleh seluruh warga kampung. Pada saat persiapan warga melakukannya secara bergotong-royong. Demikian juga pada proses pembukaan ladang diawali dengan nenteng pengawah (tebas tebang lahan) yang juga dilakukan secara bergotong royong. Budaya ini mendidik kita untuk selalu membantu sesama agar hasil yang didapatkan sesuai dengan harapan.

3. Budaya menanam padi masyarakat Dayak Kanayatn ini juga mendidik kita untuk selalu berdoa kepada Tuhan Yang Maha Esa, khususnya memohon kebaikan dalam segala hal. Hal ini nampak pada 
pelaksanaan upacara adat Nyangahatn, bahwa pelaksanaan upacara adat ini tidak hanya sekadar tradisi, tetapi juga merupakan sebuah ruang di mana orang Dayak Kanayatn dapat mendekatkan diri dengan Tuhan untuk memohon, mengadu, dan meminta perlindungan dari segala keburukan dalam hidup mereka.

4. Budaya menanam padi masyarakat Dayak Kanayatn ini pun mendidik kita untuk bisa berbagi kepada sesama. Hal ini nampak nyata khususnya pada perayaan Nyangahatn seusai panen, dimana hampir semua petani memasak hasil panen pertama, kemudian diadakan makan bersama. Mereka menyebutnya makatn nasi baharu (makan nasi baru hasil panen). Jika acara ini diadakan bersamasama, maka akan banyak nasi yang dimasak dan upacara semakin meriah.

5. Selain itu, budaya menanam padi masyarakat Dayak Kanayatn mendidik kita untuk selalu melestarikan sastra lisan dan bahasa asli yang hampir punah. Pendidikan ini nampak dari pembacaan doa dan mantera dimana hal itu merupakan bagian dari sastra lisan yang harus dijaga keberadaannya. Hal ini penting untuk menjaga tergerusnya bahasa asli Dayak Kanayatn dari gempuran bahasa Indonesia dan bahasa asing.

6. Kalau kita cermati secara mendalam lagi, ternyata dari proses menanam padi ini mendidik kita untuk bisa hidup sabar. Hal ini nampak pada budaya masyarakat Dayak Kanayatn yang masih menggunakan alat pemotong padi tradisional yaitu anai-anai, bahkan mereka menganggap tabu apabila memetik padi dengan menggunakan alat selain anai-anai. Mereka tidak mau menggunakan mesin pemotong padi meskipun mesin itu sekarang sudah ada. Mereka sangat menghormati padi dan tidak ingin menyakiti padi. Dari budaya ini mendidik kita agar bisa hidup sabar dan bisa mengasihi dengan semua makhluk Tuhan.

\section{PENUTUP}

Menanam padi, bagi masyarakat Suku Dayak Kanayatn ternyata tidak sebatas buka ladang-tanam-panen, tetapi menjadi suatu aktifitas budaya. Tanaman padi merupakan tanaman sakral bagi masyarakat Dayak, khususnya Dayak Kanayatn di Kalimantan Barat. Banyak masyarakat yang tidak menjual padi hasil panen mereka tetapi akan tetap menyimpan sebagai bahan makanan selama satu tahun. Padi ladang masyarakat Dayak terkenal enak, karena merupakan tanaman organik. Sayang, sekarang lahan mereka mulai berkurang karena tuntutan bisnis investor perkebunan sawit dan hutan tanaman industri.

Dari proses menanam padi pada Suku Dayak Kanayatn ini, dari mulai menanam hingga masa panen, kalau dicermati secara mendalam ternyata mengandung beberapa unsur pendidikan yang sangat bermanfaat bagi kita.

Mengingat banyaknya manfaat serta nilai-nilai yang bisa dipetik di balik budaya menanam padi pada masyarakat Dayak Kanayatn, maka kearifan lokal masyarakat tersebut selayaknya kita jaga kelangsungannya. Ada himbauan agar pengusaha-pengusaha besar dalam bidang perkebunan tidak semena-mena menggusur lahan pertanian masyarakat adat. Dengan terjaganya salah satu kearifan lokal tersebut, maka secara tidak langsung kita turut menjaga dan melestarikan kebudayaan nasional Indonesia.

\section{DAFTAR SUMBER}

1. Buku

Alloy, Sujarni dkk. 2008.

Mozaik Dayak. Keberagaman

Subsuku dan Bahasa Dayak di

Kalimantan Barat. Pontianak: Institut

Dayakologi.

Florus, Paulus dkk.

Kebudayaan Dayak Aktualisasi dan

Transformasi. Pontianak: Institut

Dayakologi.

Hendraswati, 1999. 
"Peranan Cerita Rakyat Bagi Masyarakat Pendukungnya (Suatu Kajian Nilai Budaya Dari Cerita Rakyat Asal Usul Padi Menurut Masyarakat Dayak Kanayatn)" dalam Laporan Penelitian Balai Kajian Jarahnitra Pontianak Nomor: 01/I/1999.

Ivo, Herman. 2001.

Gawai Dayak dan Fanatisme Rumah Panjang Sebagai Penelusuran Identitas. Pontianak: Penerbit Universitas Tanjungpura.

Langgulung, H, Husna.1987. Asas-Asas Pendidikan Islam. Jakarta.

Nila Riwut (Penyunting). 2003.

"Maneser Panatau Tatu Hiang.

Menyelami Kekayaan Leluhur.

Pengayaan Adat Istiadat dan Budaya Suku Dayak", dalam Kalimantan Memanggil dan Kalimantan Membangun, Dilengkapi Kumpulan Dokumen dan Catatan-Catatan Tjilik Riwut. Palangkaraya: Penerbit Pusakalima.

\section{Internet}

Menanam Padi dalam Semangat Budaya Dayak Kanayatn dalam http://pendakigunung.wordpress.com/2010/0 8/11/menanam-padi-dalam-semangatbudaya-dayak-kanayatn/, diunduh pada hari: Selasa, tanggal: 27 September 2011

Nyangahatn: Upacara Musim Tanam dan Panen Suku Dayak Kanayatn dalam http://melayuonline.com/ind/culture/dig/254 6/nyangahatn-upacara, diunduh pada hari: Kamis, tanggal 25 Agustus 2011.

Yohansen J. Ismail, Tujuan dan Tahapan Upacara Adat Naik Dango (Dayak Kanayatn) dalam http://beriam.blogspot.com/, diunduh pada hari: Selasa, tanggal 27 September 2011. 